\title{
The Correlation of Limestone Dust Exposure to Lung Function Impairment in Limestone Mining's Workers, Centre Java, Indonesia
}

\author{
Suyud Warno Utomo ${ }^{1,2}$, Zulfahtun Ni'mah ${ }^{1}$, Al Asyary ${ }^{1 *}$ \\ ${ }^{1}$ Department of Environmental Health, Faculty of Public Health, Universitas Indonesia, Depok, Indonesia; ${ }^{2}$ Study Program of \\ Environmental Science, School of Environmental Sciences, Universitas Indonesia, Depok, Indonesia
}

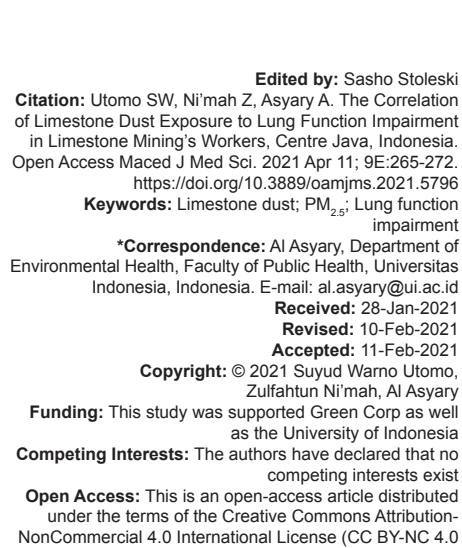

Abstract

BACKGROUND: Limestone dust is produced by limestone mining activities, one of them is PM2.5. Exposure of PM2.5 can cause lung function impairment.

AIM: The purpose of this study was to determine the correlation exposure of PM2.5 with lung function impairment in workers.

METHODS: This study used a cross-sectional study with total sampling technique of 30 workers. The instruments in this study used questionnaires for interviews, Dusttrak II TSI to measure PM2.5 concentration and spirometry to measure lung function.

RESULTS: Based on the results of the study, the highest PM2.5 concentration values were $987 \mu \mathrm{g} / \mathrm{m} 3$ and the lowest were $14 \mu \mathrm{g} / \mathrm{m} 3$. The results of the analysis using Chi-square obtained a correlation between the use of personal protective equipment with lung function impairment $(p=0.000)$. Furthermore, the results using the Fisher's exact test, there was a correlation between PM2.5 concentration and pulmonary function impairment $(p=0.002)$ and years of work with pulmonary function impairment $(p=0.000)$

CONCLUSION: Further research is needed using environmental health risk analysis to estimates based on intake.

\section{Introduction}

Industrial is one of the many aspects which boosts public's economy and welfare. As the population grows, human's needs increases, causing industrial development to become more rapid. One of the industries which have big potential for its product utilization is limestone mining. The existence of limestone mining does not only bring luck for people but can also bring harms because the industrial activities may potentially cause air pollution [1].

Air pollution becomes one of the biggest deaths causes in the world. Based on data [1], there are 7 million deaths happen every year due to ambience (outdoor) air pollution. In 2016, there were 4.2 million deaths in the world due to air pollution in low- and middle-income countries with $90 \%$ death [2]. As many as, $92 \%$ world population lives in places with air quality which exceeds the safe threshold value set by the WHO [3], and in $98 \%$ cities in low and middle-income countries, there are more than 100.000 citizens live in places which does not fill in the air guideline criteria [2]. One of the air pollutants is $\mathrm{PM}_{25}$ [4].
Exposure $\mathrm{PM}_{25}$ in a certain period of time can cause impaired pulmonary function [5]. Based on lung examination survey which was conducted by Central Java Department of Health (2013) in five regencies (Semarang, Jepara, Cilacap, Rembang, and Pekalongan), it is found that as many as $83.75 \%$ formal workers and $95 \%$ informal workers are experiencing an impaired pulmonary function. It shows that informal workers are at more risks to experience impaired pulmonary function compare to formal workers due to the lack of labors safety and health protection [6].

The industry of limestone mining is one of informal industries which process is done in a traditional way and is managed by people with a simple technology and is not really touched by legislation law. Thus, the impacts caused by it as well as the law that is related to the health protection and work safety gets less attention from the government [6]. Waste produced from the limestone mining activities is not processed nicely and caused many environmental pollutions from the processing of limestone [7]. Therefore, there is a need of research on lime dust exposure particularly $\mathrm{PM}_{2.5}$ and measurement of lungs function on limestone mining workers in Karang Dawa village district of Margasari, Tegal Regency. 


\section{Materials and Methods}

This research was conducted in the limestone mining industry in Karang Dawa, Tegal Regency. This research uses study design of cross-sectional. The independent variable in this research is the $\mathrm{PM}_{2.5}$, while the dependent variable is the impaired pulmonary function. Population in this research is all workers of the limestone mining which is as many as 30 people. The research sample is the workers located in the burning site who are more prone to the risk of being exposed with $\mathrm{PM}_{2.5}$ The sample size is determined by formulation:

$$
\begin{gathered}
n=\frac{z^{2}(1-\alpha / 2) \cdot p(1-p) N}{d^{2}(N-1)+z^{2}(1-\alpha / 2) \cdot p(1-p)} \\
n=\frac{1,96^{2} \times 0,56 \times 0,44 \times 30}{0,1^{2}(30-1)+1,96^{2} \times 0,56 \times 0,44}=22,95 \rightarrow 23
\end{gathered}
$$

Based on the sample calculation above, obtained at least as much as 23 workers' sample. However, this research uses total sampling which is as many as 30 workers. The instrument used in this research is structured questionnaire which is used to obtain the individual characteristic data. This research uses Dusttrak II TSI tool to measure $\mathrm{PM}_{2.5}$ concentration and spirometry to measure the impaired pulmonary function on the workers.

The obtained data are processed with SPSS Version 21 software. The result is analyzed in univariate and bivariate ways. Bivariate analysis uses the Chisquare and Fisher's Exact test to see the correlation between $\mathrm{PM}_{2.5}$ concentrations with $\mathrm{p}<0.005$ value. In this research, the covariate variable (age, nutrition status, history of disease, smoking habit, the use of personal protective equipment [PPE], and length of working) is also analyzed to see its correlation with the impaired pulmonary function. Meanwhile, spearman correlation test is used to analyze the environmental factors (temperature and humidity) with the environmental factors which have $\mathrm{PM}_{2.5}$ concentrations.

\section{Results}

In these past several months, the impaired pulmonary disease placed in the top three disease which is found in Karang Dawa health center. That is affected by the existence of limestone mining activity which uses the mix of hazardous and toxic materials (B3) waste in its process. The wide of the limestone mining location in Karang Dawa is about \pm 30 hectare with 15.365 population (7638 males and 7727 females).
However, only 30 people work around the burning site or chimneys of limestone mining location. The limestones burning and processing activity operates for $24 \mathrm{~h}$ a day.

\section{Individual characteristic}

The average age of the workers is 36 years old (95\% Cl: 33.84-43.22) with 12.561 deviation standard. The estimated interval result shows that $95 \%$ workers are sure to be in the age of 33.84-43.22 years old, with 39 years old as the median and 25 year old as the modus in the workers (Table 1).

Table 1: Distribution of respondent based on numeric variable (age, height, and weight) of limestone mining worker in Karang Dawa Village Tegal Regency

\begin{tabular}{lllllll}
\hline Variable & Mean & Median & Modus & DS & Min-Max & $95 \% \mathrm{Cl}$ \\
\hline Age & 36.53 & 39.00 & 25 & 12.561 & $18-61$ & $33.84-43.22$ \\
Height $(\mathrm{cm})$ & 161.83 & 160 & 160 & 7.091 & $150-176$ & $159.19-164.48$ \\
weight $(\mathrm{kg})$ & 55.13 & 55.00 & 55 & 7.528 & $40-71$ & $52.32-57.94$ \\
\hline
\end{tabular}

Based on the workers' height, it is found that the average height of the workers is $161.83 \mathrm{~cm}(95 \%$ Cl: 159.19-164.48) with deviation standard of 7.091 . The interval result shows that $95 \%$ workers are sure to have the average height of $159.19-164.48 \mathrm{~cm}$, with $176 \mathrm{~cm}$ as the median and $160 \mathrm{~cm}$ as the modus in the workers (Table 1).

From the data analysis, it is found that the average weight of the workers is $55.13 \mathrm{~kg}(95 \% \mathrm{Cl}$ : 52.32-57.94) with deviation standard of 7.091. The interval result shows that $95 \%$ workers are sure to have the average weight of $52.32-57.94 \mathrm{~kg}$, with $55 \mathrm{~kg}$ as the median and the modus in the workers (Table 1 ).

Nutrition status, workers behavior characteristic, job's characteristic, and the impaired pulmonary function

Table 2 shows that the distribution of nutrition status of the workers. It is obtained that workers with low nutrition status is as many as 5 workers (16.7\%),

Table 2: Distribution of respondents based on categorical variable of limestone mining workers in Karang Dawa Tegal

\begin{tabular}{|c|c|c|}
\hline Variable & Frequency & Percentage \\
\hline \multicolumn{3}{|l|}{ Nutrition status } \\
\hline Less $(<18.5)$ & 5 & 16.7 \\
\hline Normal (18.5-25) & 21 & 70.0 \\
\hline Higher $(>25)$ & 4 & 13.3 \\
\hline \multicolumn{3}{|l|}{ Disease history } \\
\hline No disease & 27 & 90.0 \\
\hline With disease & 3 & 10.0 \\
\hline \multicolumn{3}{|l|}{ Smoking habit } \\
\hline Non-active smoker & 2 & 6.7 \\
\hline Active smoker & 28 & 93.3 \\
\hline \multicolumn{3}{|l|}{ The use of PPE } \\
\hline Not using PPE & 19 & 63.3 \\
\hline Using PPE & 11 & 36.7 \\
\hline \multicolumn{3}{|l|}{ Working hour } \\
\hline $8 \mathrm{~h}$ & 1 & 3.3 \\
\hline$>8 \mathrm{~h}$ & 29 & 96.7 \\
\hline \multicolumn{3}{|l|}{ Working period } \\
\hline$>5$ years & 23 & 76.7 \\
\hline$\leq 5$ years & 7 & 23.3 \\
\hline \multicolumn{3}{|c|}{ Impaired pulmonary function } \\
\hline No disorder & 14 & 46.7 \\
\hline With disorder & 16 & 53.3 \\
\hline
\end{tabular}
Regency 
normal nutrition status as many as 21 workers (70\%), and higher nutrition status as many as 4 workers $(13.3 \%)$. Meanwhile, the distribution of disease's history is shown in Table 2, it is found that workers with no disease's history is as many as 27 workers (90.0\%) and workers with diseases history is as many as 3 workers $(10.0 \%)$ (Table 2).

In Table 2, the distribution of smoking habit and the use of PPE in the workers are obtained from data analysis based on workers behavior characteristic. In smoking habit, it is obtained that workers who are not active in smoking is as many as 2 workers (6.7\%) and the active ones are as many as 28 workers (93.3\%). Meanwhile, in the distribution of PPE usage, it is obtained that workers who do not use PPE is are many as 19 workers $(63.3 \%)$ and those who use it are as many as 11 workers (36.7\%).

Meanwhile, based on job's characteristic, respondent who has $8 \mathrm{~h}$ of working hour a day is 1 worker $(3.3 \%)$ and those with more than $8 \mathrm{~h}$ a day are 29 workers $(96.7 \%)$. Then, workers whose working period are more than 5 years are 23 people $(76.7 \%)$ and those whose working period is $<5$ years are 7 people $(23 \%)$ (Table 2).

The result of pulmonary function measurement to people who work in the limestone mining show that workers with no pulmonary disorders are 14 workers $(46.7 \%)$ and those with impaired pulmonary function are 16 workers $(53.3 \%)$ (Table 2$)$.

\section{$P M_{2.5}$ concentration at limestone mining}

The measurement result of $\mathrm{PM}_{2.5}$ concentrations at limestone mining location at Karang Dawa village Tegal Regency in 5 location points show that three sample points have concentration value (Threshold value) that is more than normal, which is $65 \mu \mathrm{g} / \mathrm{m}^{3}$ as stated on the Act of RI number 41 year 1999 about Air Pollution Control. The location of the sample point such as point 1 which covers chimney 2 obtains $\mathrm{PM}_{2.5}$ concentrations as big as $83 \mu \mathrm{g} / \mathrm{m}^{3}$, point 2 which covers chimney $4,5,6,7$, and 8 obtains $\mathrm{PM}_{25}$ concentrations as big as $987 \mu \mathrm{g} / \mathrm{m}^{3}$, also point 3 which covers chimney 9, 10, and 11 obtains $\mathrm{PM}_{2.5}$ concentrations as big as $202 \mu \mathrm{g} / \mathrm{m}^{3}$. Meanwhile, the measurement of $\mathrm{PM}_{2.5}$ from two sample points shows that the concentration result which is under limit value $65 \mu \mathrm{g} / \mathrm{m}^{3}$ is found such as, in point 4 , which is located in a residential area $\pm 300 \mathrm{~m}$ away from the mining location, is found to have

Table 3: Measurement result of $\mathrm{PM}_{2.5}$ at limestone mining location in Karang Dawa Regency Tegal

\begin{tabular}{|c|c|c|c|}
\hline $\begin{array}{l}\text { Sample } \\
\text { location }\end{array}$ & $\begin{array}{l}\text { Concentration of } \mathrm{PM}_{2.5} \\
\left(\mu \mathrm{g} / \mathrm{m}^{3}\right)\end{array}$ & $\begin{array}{l}\text { Level of concentration } \\
\text { value (Threshold) }\end{array}$ & Annotation \\
\hline Point 1 & 83 & 65 & More than threshold \\
\hline Point 2 & 987 & 65 & More than threshold \\
\hline Point 3 & 202 & 65 & More than threshold \\
\hline Point 4 & 14 & 65 & Under threshold \\
\hline Point 5 & 39 & 65 & Under threshold \\
\hline
\end{tabular}

concentration result as high as $14 \mu \mathrm{g} / \mathrm{m}^{3}$ and point 5 , which is located in the enter gate of the mining location and residential area, is found to have concentration result as high as $39 \mu \mathrm{g} / \mathrm{m}^{3}$ (Table 3 ).

\section{$P M_{2.5}$ concentration and environmental factors (temperature and humidity)}

Based on data analysis, it is obtained that the average $\mathrm{PM}_{2.5}$ concentrations are as big as 455.63 (95\% Cl: 289.39-621.87) from the distribution of $\mathrm{PM}_{2.5}$ concentrations at 5 limestone mining location points. From 95\% interval analysis result, it is believed that the average concentration of $\mathrm{PM}_{2.5}$ is from 289.39 to 621.87 with deviation standard of 445.201 and median of $202.00 \mu \mathrm{g} / \mathrm{m}^{3}$. The lowest concentration value of $\mathrm{PM}_{2.5}$ is $14 \mu \mathrm{g} / \mathrm{m}^{3}$ and the highest is $39 \mu \mathrm{g} / \mathrm{m}^{3}$ (Table 4).

Table 4: Distribution of $\mathrm{PM}_{2.5}$ concentration and environmental factors (temperature and humidity) at limestone mining location in Karang Dawa Tegal Regency

\begin{tabular}{llllll}
\hline Variable & Mean & Median & DS & Min-Max & $95 \% \mathrm{Cl}$ \\
\hline $\mathrm{PM}_{2.5}$ concentration & 455.65 & 202.00 & 445.201 & $14-987$ & $289.39-621.87$ \\
Temperature & 36.50 & 35.38 & 1.734 & $33.83-38.70$ & $35.85-37.15$ \\
Humidity & 45.93 & 45.45 & 3.480 & $39.90-50.35$ & $44.63-47.23$ \\
\hline
\end{tabular}

The measurement of environmental value (temperature and humidity) which is measured at the 5 points which are close to the $\mathrm{PM}_{2.5}$ measurement obtains a result which is shown in Table 3 . It is found that the average temperature at 5 location points in limestone mining location is $36.50^{\circ} \mathrm{C}(95 \% \mathrm{Cl}$ : $35.85-$ 37.15). From $95 \%$ interval analysis, it is believed that the average temperature is from 35.85 to $37.15^{\circ} \mathrm{C}$ with deviation standard of 1.734 and median of $35.38^{\circ} \mathrm{C}$. The lowest temperature in the limestone mining location is $33.83^{\circ} \mathrm{C}$ and the highest is $38.70^{\circ} \mathrm{C}$. Meanwhile, it is found that the average humidity at the 5 location points is 45.93 (95\% Cl: 44.63-47.23). From $95 \%$ interval analysis, it is believed that the average humidity is from 44.63 to 47.23 with deviation standard of 3.480 and median of 45.45 . The lowest humidity in the limestone mining location is 39.90 and the highest is 50.35 (Table 4).

\section{function}

\section{Case study of decreased pulmonary}

In Table 5, it can be seen that analysis test result from two variable data between age and impaired pulmonary function shows that the result in Table $2 \times 2$ does not meet the Chi-square test requirement because there is expected value that is lower than five. The alternative analysis used by the researcher is Fisher's Exact Test. Statistical analysis result shows that there are $5(45.5 \%)$ workers with age $\leq 35$ years old have impaired pulmonary function and 11 (57.9\%) workers with age $>35$ years old have impaired pulmonary function with $p=0.078$ which means that there is no correlation between age and impaired pulmonary function. 
Based on the workers nutritional status, workers with abnormal nutritional status who have impaired pulmonary function is 5 workers $(71.4 \%)$ and workers with normal nutritional status who have impaired pulmonary function is 11 workers (71.4) with $p=0.399$ which means that there is no correlation between nutritional status with impaired pulmonary status on mining workers at Karang Dawa Village in Tegal Regency 2019.

Limestone mining workers who have disease history and experience impaired pulmonary function is 11 workers (33.3\%) and workers who has no disease history and experience impaired pulmonary function is 15 workers (55.6\%). Statistical result gets $p=0.586$ which means that there is no correlation between disease history with impaired pulmonary function on mining workers at Karang Dawa Village in Tegal Regency.

The result from smoking habit data analysis with impaired pulmonary function shows that there are 16 workers (57.1\%) who actively smoke also experience impaired pulmonary function and 0 workers $(0 \%)$ who do not smoke and experience impaired pulmonary function. Statistical test result shows that $p=0.209$ which means that there is no correlation between smoking habit with impaired pulmonary function on mining workers at Karang Dawa Village in Tegal Regency.

PPE usage data analysis with impaired pulmonary function on the mining's workers shows that there are 10 workers (52.6\%) who do not wear PPE when working experiencing impaired pulmonary function and there are 6 workers (54.5\%) who wear PPE when working experiencing impaired pulmonary function. Statistics shows that $p=0.000$ which means that there is a correlation between the usage of PPE with impaired pulmonary function on the limestone mining workers.

The length of working hours' data analysis with impaired pulmonary function on the mining's workers shows that there are 0 workers $(0 \%)$ whose working hours is $8 \mathrm{~h}$ experiencing impaired pulmonary function. Meanwhile, there are 16 workers (55.2\%) whose working hours is $>8 \mathrm{~h}$ experiencing impaired pulmonary function. Statistics shows that $p=0.467$ which means that there is no correlation between the length of working hours with impaired pulmonary function on the limestone mining workers at Karang Dawa Village Tegal Regency (Table 5).

\section{The correlation between $P_{25}$} concentration with impaired pulmonary function

The analysis result between $\mathrm{PM}_{2.5}$ concentrations with impaired pulmonary function shows that there is 0 worker $(0.0 \%)$ experiencing impaired pulmonary function with $\mathrm{PM}_{25}$ concentrations under the threshold value. Meanwhile, there are 16 workers
Table 5: Correlation of covariate variables with impaired pulmonary function

\begin{tabular}{|c|c|c|c|c|c|c|c|}
\hline & \multicolumn{4}{|c|}{ Impaired pulmonary function } & \multirow{3}{*}{$\begin{array}{l}\text { Total } \\
\mathrm{n}\end{array}$} & \multirow[t]{3}{*}{$\%$} & \multirow[t]{3}{*}{$p$ value } \\
\hline & \multicolumn{2}{|c|}{ No impairment } & \multicolumn{2}{|c|}{ With impairment } & & & \\
\hline & $\mathrm{n}$ & $\%$ & $n$ & $\%$ & & & \\
\hline \multicolumn{8}{|l|}{ Age } \\
\hline$\leq 35$ years old & 6 & 54.5 & 5 & 45.5 & 11 & 100 & 0.078 \\
\hline$>35$ years old & 8 & 42.1 & 11 & 57.9 & 19 & 100 & \\
\hline \multicolumn{8}{|l|}{ Nutritional status } \\
\hline Normal & 12 & 52.2 & 11 & 47.8 & 23 & 100 & 0.399 \\
\hline Abnormal & 2 & 28.6 & 5 & 71.4 & 7 & 100 & \\
\hline \multicolumn{8}{|l|}{ Disease history } \\
\hline Yes & 12 & 44.4 & 15 & 55.6 & 27 & 100 & 0.586 \\
\hline No & 2 & 66.7 & 1 & 33.3 & 3 & 100 & \\
\hline \multicolumn{8}{|l|}{ Smoking habit } \\
\hline Active & 2 & 100 & 0 & 0 & 2 & 100 & 0.209 \\
\hline Non-active & 12 & 42.9 & 16 & 57.1 & 28 & 100 & \\
\hline \multicolumn{8}{|c|}{ The use of protecting tools } \\
\hline No & 9 & 47.4 & 10 & 52.6 & 19 & 100 & 0.000 \\
\hline Yes & 5 & 45.5 & 6 & 54.5 & 11 & 100 & \\
\hline \multicolumn{8}{|l|}{ Working hours } \\
\hline $8 \mathrm{~h}$ & 1 & 100 & 0 & 0.0 & 1 & 100 & 0.467 \\
\hline$>8 \mathrm{~h}$ & 13 & 44.8 & 16 & 55.2 & 29 & 100 & \\
\hline \multicolumn{8}{|l|}{ Working period } \\
\hline$>5$ years & 11 & 47.8 & 12 & 52.5 & 23 & 100 & 0.000 \\
\hline$\leq 5$ years & 3 & 42.9 & 4 & 57.1 & 7 & 100 & \\
\hline
\end{tabular}

(69.6\%) with $\mathrm{PM}_{2.5}$ concentrations more than the threshold value experiencing impaired pulmonary function. Chi-square test result shows that $p=0.002$ which means that there are proportion differences of impaired pulmonary function on the workers with $\mathrm{PM}_{2.5}$ concentrations. Statistically, there is correlation between $\mathrm{PM}_{2.5}$ concentrations with impaired pulmonary function on the workers (Table 6).

Table 6: Correlation between exposure of limestone dust concentration $\left(\mathrm{PM}_{2.5}\right)$ with impaired pulmonary function on limestone mining workers at Karang Dawa Village Tegal Regency

\begin{tabular}{|c|c|c|c|c|c|c|c|}
\hline \multirow[b]{3}{*}{$\mathrm{PM}_{2.5}$} & \multicolumn{4}{|c|}{ Impaired pulmonary function } & \multirow{3}{*}{$\begin{array}{l}\text { Total } \\
\mathrm{n}\end{array}$} & \multirow[t]{3}{*}{$\%$} & \multirow[t]{3}{*}{$p$ value } \\
\hline & \multicolumn{2}{|c|}{ No impairment } & \multicolumn{2}{|c|}{ With impairment } & & & \\
\hline & $\mathrm{n}$ & $\%$ & $\mathrm{n}$ & $\%$ & & & \\
\hline Under threshold value & 7 & 100.0 & 0 & 0.0 & 7 & 100 & 0.002 \\
\hline More than threshold value & 7 & 30.4 & 16 & 69.6 & 23 & 100 & \\
\hline
\end{tabular}

\section{Analysis of environmental factors with $P M_{2.5}$ concentration}

Based on Table 7, the result of environmental factors data is obtained. In the correlation of temperature and $\mathrm{PM}_{2.5}$ concentrations, $\mathrm{p}=0.233$, which shows that the correlation between temperature and $\mathrm{PM}_{2.5}$ concentrations is meaningless because $p>0.01$. The value of spearman correlation is 0.225 shows negative correlation which means it has weak power.

Table 7: Environmental factors analysis (temperature and humidity) and $\mathrm{PM}_{2.5}$ concentration

\begin{tabular}{ll}
\hline $\mathrm{PM}_{2.5}$ concentration & \\
\hline Temperature & $\mathrm{r}=-0.225$ \\
& $\mathrm{p}=0.233$ \\
Humidity & $\mathrm{n}=30$ \\
& $\mathrm{r}=0.087$ \\
& $\mathrm{p}=0.648$ \\
$\mathrm{n}=30$
\end{tabular}

Meanwhile, on the humidity with $\mathrm{PM}_{2.5}$ data analysis result, it is obtained that $p=0.648$ which shows that the correlation between humidity and $\mathrm{PM}_{2.5}$ concentrations is meaningless because $p>0.01$. However, spearman correlation value which is 0.087 shows a positive correlation which means that it has strong power. 


\section{Discussion}

\section{Individual characteristic}

Analysis result of correlation between age and impaired pulmonary function obtains that there are 5 workers whose age are $\leq 35$ experiencing impaired pulmonary function (45.5\%) and 11 workers whose age are $>35$ are experiencing impaired pulmonary function $(57.9 \%)$. That result shows that $p=0.078$ which means that there is no correlation between age and impaired pulmonary function on the limestone mining workers. This research matches with the one conducted in cement factory which declares that workers whose age are $>35$ and above have risks of experiencing impaired pulmonary function compared to workers whose age are less than or same with 35 years old [8]. Based on theory, lungs will experience a decrease in function after someone is above 35 years old. It is because when someone is above 35 years old there will be changes on the physical form such as the changes in muscles and bones, changes of lungs' tissue, and changes of nerve system [9].

In the analysis of nutritional status with impaired pulmonary function, $p=0.399$ which means that there is no correlation between nutritional status with impaired pulmonary function. There are 11 workers (47.8\%) with normal nutritional status who are experiencing impaired pulmonary function. Meanwhile, there are 5 workers $(71.4 \%)$ with abnormal nutritional status who are experiencing impaired pulmonary function. This matches with the research conducted at cement industry in 2017 which shows that there is no meaningful correlation statistically [10]. Another matched research with this research is the one conducted by Riski, the research which was conducted in Tanjung Priok Harbor shows $p=0.48$ with $\mathrm{OR}=1.5(95 \% \mathrm{Cl}=0.5-0.46)$. It means that there is no significant correlation between workers' nutritional status with the chronic obstructive pulmonary disease (COPD) experienced by workers in Tanjung Priok Harbor, and the workers with abnormal nutritional state have 1.5 times higher risk to get COPD than those who have normal nutritional state [11].

Theoretically, lack of nutrition on someone causes low weight, where a low weight can cause a decrease on respiratory muscle's power and the increase of mortality. If someone is overweight, it can decrease lungs' vital capacity so it causes heavy lung's impairment. Overweight can cause chronic diseases, meanwhile improper body weight can affect the function of respiratory bones and muscles [12].

In this research, disease history does not have any correlation with impaired pulmonary function. The result of this research matches with the research conducted by Zikri at a cement factory in Bogor which stated that history of respiratory disease does not have any correlation with impaired pulmonary function [10]. However, ithas $2 \mathrm{OR}$ value, which means that workers who have history of respiratory disease have 2 times higher risk of getting impaired pulmonary function than those who do not. Based on theory, there are several diseases which can cause pulmonary function impairment such as tuberculosis, bronchitis, emphysema, pneumonia, shortness of breath due to allergies, asthma, and sinusitis which can cause abnormal result of pulmonary function measurement [13].

\section{Workers behavior characteristics}

This research found that there is no correlation between smoking habits with impaired pulmonary function on the limestone mining workers. A parallel research was done by Putra et al. to parking officers in Pandanaran Street Semarang. Using the spearman correlation test, it gets a conclusion that there is no significant correlation between smoking habits with KVP value. This is not in sync with the theory which mentions that smoking can cause pulmonary function's impairment [14]. The WHO also stated that smoking is the highest cause of death which is preventable. Smoking can add the risk of getting heart disease to 2-4 times higher compare to those who are not active smokers. Smoking can also increase the risk of death because of lungs cancer. Those incompatibilities are affected by the lack of data's accuration about the amount of cigarettes consumed in a day [3].

Meanwhile, the use of PPE has a significant correlation with impaired pulmonary function. The result of this research matches with the research conducted by Afiani which stated that there are correlations between the used of PPE with the existence of pulmonary function impairment [15]. It can be understood by the fact that there are $18.2 \%$ workers who wear masks still experience impaired pulmonary function. Several factors which cause the use of PPE to be less maximum such as the unsuitable masks to wear, wrong way to use the masks, broken masks, and no sanction for workers who do not wear PPE so that many of them take it lightly [16].

\section{Job's characteristics}

The result of statistical test of working period with impaired pulmonary function found that $p=0.46$ which means that there is no correlation between working period with impaired pulmonary function. Workers in limestone industry have different working period, if it is compared to the Act number 13 Year 2003, the workers of limestone mining with working period and days are above the threshold standard.

Working period is a period of time when someone starts their job for the $1^{\text {st }}$ time until the time when the research is conducted [17]. The analysis result of the correlation between working period and impaired pulmonary function in the limestone mining workers shows that workers whose working period is more than 5 years have higher risk to experience 
impaired pulmonary function than those whose working period is $<5$ years. Based on Kusnoputranto's theory (1990) states that the longer someone is working, the higher risk of them getting diseases due to their jobs.

\section{location}

\section{$P M_{2.5}$ concentration in limestone mining}

$\mathrm{PM}_{2.5}$ is a particle that has diameter $\leq 2.5 \mu \mathrm{m}$. $\mathrm{PM}_{2.5}$ cannot be seen with bare eyes; the size of this particle is said to be $3 \%$ of a human's hair size [18]. The source of $\mathrm{PM}_{2.5}$ on this research comes from the burning and processing activity of limestone which uses the mix of hazardous and toxic waste. The measurement of $\mathrm{PM}_{2.5}$ in limestone mining location was conducted at morning and evening. The measurement of $\mathrm{PM}_{2.5}$ was conducted in 5 limestone mining location points with 60 min each. Every second of sample taking can represent burning sites or chimneys for limestone burning. The measurement of $\mathrm{PM}_{2.5}$ concentrations was conducted when the weather is good and not raining.

Based on the measurement of $\mathrm{PM}_{2.5}$ in the limestone mining location, it is found that the average of $\mathrm{PM}_{2.5}$ concentrations is $455.6 \mu \mathrm{g} / \mathrm{m}^{3}$. The highest $\mathrm{PM}_{2.5}$ concentrations are $987 \mu \mathrm{g} / \mathrm{m}^{3}$ which is found in point 2 which is located between burning sites or chimneys 4, 5, 6, 7, and 8. Meanwhile, the lowest $\mathrm{PM}_{2.5}$ concentrations are found in point 4 which are located in the resident's area that is close to the burning site. There are 3 measurement points for $\mathrm{PM}_{2.5}$ that pass over the threshold limit value which is stated by Act of Republic Indonesia number 41 Year 1999 about the Air Pollution Control which is $65 \mu \mathrm{g} / \mathrm{m}^{3}$ within $24 \mathrm{~h}$. The high and low of $\mathrm{PM}_{2.5}$ concentrations are affected by environmental factors such as temperature, humidity, wind speed, and wind direction.

\section{humidity) \\ Environmental factors (temperature and}

In the research's result, environmental factors (temperature and humidity) show different correlation. In temperature with $\mathrm{PM}_{2.5}$ concentrations, it shows negative correlation. Meanwhile, in humidity with $\mathrm{PM}_{2.5}$ concentrations, it shows positive correlation so that statistically there is no meaningful correlation between environmental factors and $\mathrm{PM}_{2.5}$ concentration.

Temperature has negative correlation with $\mathrm{PM}_{2.5}$ concentrations $(r=-0.225)$ which means that it has weak correlation power. It is caused by when the temperature rises then $\mathrm{PM}_{2.5}$ concentrations will go down. It matches with the research conducted by Fathamaulida which stated that temperature and $\mathrm{PM}_{2.5}$ concentrations because it can be affected by wind turbulence factor [19]. Wind can lower a quite high temperature so that it can minimize $\mathrm{PM}_{2.5}$ concentrations $(r=0.087)$ meaning that there is a strong power. It matches with the research conducted by Yao et al. which shows that humidity relatively will be followed by the increase of $\mathrm{PM}_{2.5}$ concentrations [20].

\section{The correlation of $P M_{2.5}$ with impaired pulmonary function}

Impaired pulmonary function on the workers can be known from the result of pulmonary function measurement using spirometry. Spirometry becomes an alternative to know someone's lungs condition because it is said to be easy, practical, and accurate. The measurement result of spirometry will produce Forced Vital Capacity (FVC) and Force Expiratory Volume $\left(F E V_{1}\right)$ value. If the comparison of $F_{1} V_{1}$ value and $F V C$ value is $<70 \%$, then it can be categorized that one has impaired pulmonary function. Meanwhile, if the comparison is $\geq 70 \%$ so it can be categorized as normal or there is no impaired pulmonary function.

In this research, it is obtained that the value of $p=0.002$, which means that there is correlation between $\mathrm{PM}_{2.5}$ with impaired pulmonary function on the limestone mining workers. This research shows meaningful correlation between PM2.5 correlations with impaired pulmonary function on adults at industrial sites in Pulogadung, East Jakarta. Another research conducted in limestone industrial site in Grobogan shows that workers who are exposed to impaired pulmonary function are those who have dust exposure above the threshold limit value [21].

\section{Conclusions}

Based on the result obtained from this research, it can be concluded that:

1. The average $\mathrm{PM}_{2.5}$ concentrations which is measured in 5 limestone mining location points in Karang Dawa Village Tegal Regency are $455.63 \mu \mathrm{g} / \mathrm{m}^{3}$. The highest $\mathrm{PM}_{2.5}$ concentrations are $987 \mu \mathrm{g} / \mathrm{m}^{3}$ and the lowest $\mathrm{PM}_{2.5}$ concentrations are $14 \mu \mathrm{g} / \mathrm{m}^{3}$.

2. The average $\mathrm{PM}_{2.5}$ concentration value is over threshold limit value which is based on Act of Republic Indonesia Number 41 Year 1999 about Air Pollution Control which is $65 \mu \mathrm{g} / \mathrm{m}^{3}$. The are 16 workers (53.3\%) who experience impaired pulmonary function, meanwhile there are 14 workers $(46.7 \%)$ who are not experiencing impaired pulmonary function.

3. There is significant correlation between the use of self-protecting tools with impaired pulmonary function $(p=0.000)$. There is significant correlation between working period with impaired pulmonary function on limestone mining workers $(p=0.000)$ and there is no correlation between factors (age, nutritional 
status, disease history, smoking habit, working frequency, temperature, and humidity).

4. There is a significant correlation between $\mathrm{PM}_{2.5}$ concentrations with impaired pulmonary function $(p=0.002)$.

\section{Author Contributions}

Conceptualization, SWU and $\mathrm{ZH}$; methodology, SWU and AA; software, $\mathrm{ZH}$; validation, SWU and $\mathrm{ZH}$; formal analysis, SWU and $A A$; investigation, SWU and $\mathrm{ZH}$; resources, SWU; data curation, SWU and $\mathrm{ZH}$; writing-original draft preparation, SWU; writingreview and editing, $\mathrm{ZH}$ and $\mathrm{AA}$; visualization, SWU; supervision, SWU; project administration, $\mathrm{ZH}$; funding acquisition, SWU. All authors have read and agreed to the published version of the manuscript.

\section{Acknowledgments}

We thank to all staff of the Environmental Health Department, Faculty of Public Health, Universitas Indonesia which had been facilitated Education and research facilities including discussion rooms, libraries, the internet, and lecturers who are always supportive. Administrative staff who always help during the study.

\section{References}

1. World Health Organization. 7 Million Premature Deaths Annually Linked to Air Pollution. Geneva: World Health Organization; 2019. Available from: http://www.who.int/mediacentre/news/ release/2014/airpollution/e/en. [Last accessed on 2019 Feb 09].

2. World Health Organization. Ambient (Outdoor) Air Quality and Health. Geneva: World Health Organization; 2019. Available from: http://www.who.int/mediacentre/factsheets/fs313/en. [Last accessed on 2019 Feb 09].

3. World Health Organization. Air Pollution. Geneva: World Health Organization; 2019. Available from: http://www.who.int/topics/ air-pollution/e/en. [Last accessed on 2019 Mar 17]

4. Esteban JL. Human health variations in PM10-PM2,5 and associated PAHs levels. J Elsevier Sci. 2017;160:27-35.

5. Kioumortzoglou MS. Long Term PM2,5 exposure and neurological hospital admissions in the Northeastern United States. Environ Health Perspect. 2016;124(1):23-9.

6. Dinas Kesehatan Provinsi Jawa Tengah. Profil Kesehatan Provinsi Jawa Tengah Tahun 2017 [Central Java Health Profile of 2017]. Indonesia: Central Java Public Health Office; 2017. Available from: http://www.depkes.go.id/resources/download/ profil/profil_kes_provinsi_2017/13_jateng_2017.pdf. [Last accessed on 2019 Apr 12]. https://doi.org/10.22146/bkm.37637
7. Sucipto, E. Hubungan Pemaparan Partikel Debu Pada Pengolahan Batu Kapur Terhadap Penurunan Kapasitas Fungsi Paru [The Correlation between Dust Particle Exposure on Lime Stone Production to The Decrease of Pulmonary Function], Undergraduate Thesis. Indonesia: Faculty of Public Health, Diponegoro University; 2007.

8. Komariah VH. Analisis Risiko PM2,5 dan Dampaknya Terhadap Penurunan Fungsi Paru Pekerja Industri Semen di Plant 06 PT. Indocement Citeureup-Bogor Tahun 2016 [Risk Analysis of PM2.5 and Its Effect on The Decrease of Pulmonary Function of Cement Industry's Workers in Indocement Ltd. CitereupBogor 2016], Undergraduate Thesis. Indonesia: Public Health Undergraduate Program Faculty of Public Health, University of Indonesia; 2016. https://doi.org/10.31258/dli.1.2.p.124-129

9. American Lung Association, Lung Capacity and Aging; 2018. Available from: http://www.lung.org/lung-health-and-disease-/ how-lungs-work/lung-capacity-and-aging.html?referrer=https:// www.google.co.id. [Last accessed on 2019 Mar 20].

10. Zikri RB. Analisis Konsentrasi PM2,5 Terhadap Penurunan Fungsi Paru Pada Pekerja Industri Semen Di Pabrik Bogor PT.X, Kabupaten Bogor Tahun 2017 [Analysis of PM2,5 Concentration on the Decrease of Pulmonary Function of Cemen Industry's Workers in Bogor Factory X Ltd., Bogor Regency 2017]. Indonesia: Faculty of Public Health, University of Indonesia; 2017. https://doi.org/10.14692/jfi.13.4.119

11. Riski M. Hubungan Pajanan PM2,5 Terhadap Penyakit Paru Obstruktif Kronik (PPOK) Pada Pekerja di Pintu Gerbang Pelabuhan Tanjung Priok Tahun 2018 [The Correlation of PM2.5 Exposure to the Chronic Obstructive Pulmonary Disease (COPD) of Workers in Tanjung Priok's Port's Gate 2018]. Indonesia: Fakultas Kesehatan Masyarakat, University of Indonesia; 2018. https://doi.org/10.6066/jtip.2014.25.1.31

12. Azad A, Zamani A. Lean body mass can predict lung function in underweight and normal weight sedentary female young adult. Tanaffos. 2014;13(2):20-6.

PMid:25506372

13. West JB, Luks A. West's Pulmonary Pathophysiology: The Essentials. $9^{\text {th }}$ ed. Philadelphia, PA: Wolters Kluwer; 2017.

14. Putra DP, Rahmatullah $P$, Novitasari $A$. Hubungan usia, lama kerja, dan kebiasaan merokok dengan fungsi paru pada juru parkir di jalan Pandanaran Semarang [The correlation between age, working period and smoking habit with pulmonary function on parking officers in Pandanaran street Semarang]. Muhammadiyah Med J. 2012;1(2):7-12. https://doi. org/10.23917/jurkes.v10i2.5529

15. Afiani EE, Jayanti S, Widjasena B. Faktor-faktor yang berhubungan dengan gangguan fungsi paru pada pekerja di unit boiler industri tekstil X Kabupaten Semarang [Factors which correlate with pulmonary impairment on workers of textile $x$ industry broiler unit Semarang Regency]. J Public Health. 2016;4:2356-3346. https://doi.org/10.15294/ujph.v5i2.10122

16. Fahmi T. Hubungan masa kerja dan penggunaan APD dengan kapasitas fungsi paru pada pekerja tekstil bagian ring frame spinning I di X Ltd. Kabupaten Pekalongan [The correlation of working period and the use of PPE with the pulmonary function capacity on the textile workers of ring frame spinning unit in $X$ Ltd. Pekalongan]. J Public Health. 2012;9:828-35. https://doi. org/10.31227/osf.io/h4gj2

17. Zainudin AA. Kebijakan pengelolaan kualitas udara terkait transportasi di provinsi DKI Jakarta [The air quality management in relation to transportation in DKI Jakarta Province]. J Public Health. 2010;4(6):281-8. https://doi.org/10.21109/kesmas. v4i6.168

18. EPA, National Ambient Air Quality of Particle Pollution; 2019. Available from: https:/www.epa.gov/criteria-air-pollutants/ naaqs-table. [Last accessed on 2019 Apr 12].

19. Fathamaulida A. Faktor-faktor Yang Berhubungan Dengan 
Gangguan Fungsi Paru Pada Pekerja Pengolahan Batu Kapur Di Desa Tamansari Kabupaten Karawang Tahun 2013 [Factors Which Correlate with The Pulmonary Impairement on Lime Stone Mining Workers in Tamansari Village Karawang 2013]. Jakarta: State Islamic University of Syarif Hidayatullah; 2013. https://doi.org/10.51352/jim.v1i2.37

20. Yao HQ, Choi HL, Lee JH, Suresh A, Zhu K. Effect of microclimate on particulate matter, airborne bacteria, and odorous compounds in swine nursery houses. J Anim Sci.
2010;88(11):3707-14. https://doi.org/10.2527/jas.2009-2399 PMid:20601522

21. Yulaekah SA. Pajanan debu terhirup dan gangguan fungsi paru pada pekerja industri batu kapur (studi di desa mrisi kecamatan tanggungharjo kabupaten grobogan) [Inhalled dust exposure and pulmonary impirement on thr lime stone mining workers (A research in mrisi village tanggungharjo district gribogan)] J Public Health. 2007;6(1):24-31. https://doi.org/10.14710/ jil.11.1.16-23 